\title{
Article
}

\section{Inclusive Education for Religious Minorities: The Syriacs in Turkey}

\author{
Halis Sakız ${ }^{1, *}$, Abdurrahman Ekinci ${ }^{1}$ and Güldest Baş ${ }^{2}$ \\ ${ }^{1}$ Department of Educational Sciences, Mardin Artuklu University, 47200 Mardin, Turkey; \\ E-Mails: halissakiz@artuklu.edu.tr (H.S.), abdurrahmanekinci@artuklu.edu.tr (A.E.) \\ 2 Department of Psychology, Mardin Artuklu University, 47200 Mardin, Turkey; E-Mail: guldestbas@artuklu.edu.tr \\ * Corresponding author
}

Submitted: 30 March 2020 | Accepted: 27 July 2020 | Published: 20 August 2020

\begin{abstract}
Expanding the scope of inclusion beyond specific groups such as individuals with disabilities has led to the investigation of school systems' inclusiveness from the perspective of all students. With this in mind, this research investigated the experiences of students and parents belonging to the ancient Syriac community in Turkey, who inhabited Mesopotamia since the inception of Christianity. Obtaining the views of 43 parents and their 46 children through semi-structured interviews, the school system was investigated at a political, cultural, and practical level in terms of the educational inclusion of Syriac individuals. Overall, student and parent views indicated that: (a) policy-making lacked an approach to reach all students and organize support for diversity; (b) school cultures needed to build a community whereby inclusive values were established; and (c) school practices lacked the organization to target and ensure the learning of all and mobilize resources to achieve this aim. Details of findings are included and discussed. Implications address the importance of building schools that consider the increasingly diverse school populations around the world, with a particular focus on cultural and religious diversity.
\end{abstract}

\section{Keywords}

inclusive education; learning; religion; school system; Syriacs; Turkey

\section{Issue}

This article is part of the issue "Religious Minorities and Struggle for Recognition" edited by Christophe Monnot (University of Lausanne, Switzerland/University of Strasbourg, France) and Solange Lefebvre (University of Montreal, Canada).

(C) 2020 by the authors; licensee Cogitatio (Lisbon, Portugal). This article is licensed under a Creative Commons Attribution 4.0 International License (CC BY).

\section{Introduction}

Education is a fundamental human right (United Nations General Assembly, 1949, Article 26). Inclusive education is defined as the process of responding to different needs of learners, increasing their participation in education, culture, and society, and reducing discrimination within the education system (UNESCO, 2009). The expansion of the scope of inclusion has provided the opportunity to talk about the inclusion of various marginalized groups in society, including minorities. Article 27 of the United Nations Declaration on the Rights of Persons Belonging to National or Ethnic, Religious and Linguistic Minorities (United Nations General Assembly, 1949) declares that:
In those States in which ethnic, religious or linguistic minorities exist, persons belonging to such minorities shall not be denied the right in community with the other members of their group, to enjoy their own culture, to profess and practise their own religion, or to use their own language.

The minorities are therefore given an extra right in addition to other rights stated by various conventions. Turkey is a member state of the United Nations. Thus, the State needs to comply with the standards and make sure not to deny rights to members belonging to minorities. Therefore, everyone should be provided with the right to reach and benefit from quality education through inclusive approaches. However, the question of what mecha- 
nisms should be possessed by school systems for the inclusion of individuals of minority groups needs to be solved.

Recent conceptualizations of inclusion look for inclusion from the perspective of all, especially those who are likely to get marginalized within the system. To ensure that students are included within the schools, theoretical frameworks propose to investigate the policy, culture, and practices of schools, and therefore analyze school systems in a holistic perspective (e.g., Booth \& Ainscow, 2002; Dyson, Howes, \& Roberts, 2002; Salend, 2011). The key concepts of inclusion are: (i) removing barriers to learning and participation; (ii) allocating resources to support learning and participation; and (iii) providing support for diversity. Also, this perspective provides ground for the voice of marginalized individuals and groups to get heard. In this study, students and parents of the ancient Syriac community are given a chance to comment on their educational experiences from the perspective of inclusion.

\section{The Syriac Community in Turkey}

Having been characterized as an intersection between Eastern and Western cultures, Turkey is a heterogeneous country with a total population of $83,154,997$ (Turkish Statistical Institute, 2020). The largest ethnic group in Turkey are the Turks, which makes sense as Turkey was built as a nation-state. Still, the Jews, Greeks, and Armenians are all protected under the Turkish Constitution, despite having very small numbers. According to Içduygu, Toktas, and Soner (2008), the population of the Jews, Greeks, and Armenians in Turkey in 2005 was 27,000, 3,000, and 50,000, respectively. Since the inception of nationalism waves, which roughly correspond to the last 130 years, the ethnic group of Syriacs has been reduced significantly in the areas previously dominated by them (Bardakci, FreybergInan, Giesel, \& Leisse, 2017). Currently, they constitute a population between 15,000 and 25,000 according to the origin of modern sources. From this number, there are about 10,000-15,000 in Istanbul and 2,000-3,000 in the Mardin area in Southeast Turkey (Thomsen, 2008). In both cities, the Syriacs live with a predominantly Muslim population. The majority of the Syriacs have left Turkey and currently live in the diaspora. The Syriacs are an officially unacknowledged non-Muslim minority group that is deprived of minority status (Bardakci et al., 2017). Indeed, there are several officially unacknowledged minority groups such as Circassians, Georgians, and Lazs who possess an approximate population of 2,500,000, $1,000,000$, and 2,250,000, respectively.

Syriacs' historical origins are considered as ancient. Their heritage dates back to early Mesopotamian civilizations. The Syriacs comprise a religious and, at the same time, an ethnic minority. The term Syriac refers to a very heterogeneous ethnic group, whose members belong to the Eastern Christian churches of the Syriac tradition, whose services tend to feature liturgical language use of ancient Syriac, namely Middle Aramaic (Bardakci et al., 2017). For hundreds of years, Syriacs have lived as a minority group with a different cultural and religious identity under different powers in the Middle East. In terms of language, culture, and church, the Syriac community is heterogeneous. Having spread around the Middle East, the Syriacs speak different dialects of the Syriac language as well as Turkish, Arabic, Kurdish, and Persian. The minority position and cultural unity have resulted in increased solidarity within the community (Thomsen, 2008).

Although the Syriac identity is a salient one in Turkey, Syriacs-unlike other non-Muslim minorities such as Greeks, Jews, and Armenians-do not have law-abided schools. To receive a formal education, Syriac students attend public and private mainstream schools that are run by the Ministry of National Education under a centralized curriculum. Within this curriculum, Syriac children attend regular classrooms and receive the same pedagogical content. However, the extent to which Syriac individuals are satisfied with the attempts of the educational system to meet their individual, educational, and cultural needs is questionable. One of the main reasons for this is the compulsory Religious Culture and Moral Education course which targets Muslim students and is based on the religion of Islam and the Turkish culture (Yıldız, 2009). According to the current Turkish Constitution, adopted in 1982, Article 2 describes the Turkish State as a "democratic, secular and social state" while, at the same time, Article 24 gives the state control over education and instruction in religious ethics and mandates instruction in religious culture and moral education (Yıldız, 2007). Nonmuslim communities in Turkey claim that if the state controls educational activities, its democratic and social structure requires equitable provision based on the needs of everyone living in the state (Yıldız, 2002).

During the Religious Culture and Moral Education course, students from officially unrecognized minority groups such as the Syriacs have the right to withdraw from the course and obtain exemption (Yıldız, 2009). However, they are not given an alternative course based on their religion and culture. Instead, to receive education in line with their belief system and language, Syriac children attend afternoon lessons in community-owned informal Syriac schools after their state education is completed in the mornings. This informal instruction is still valid and mostly takes place in community-owned churches.

\section{Turkey's Case of Inclusion}

In Turkey, all educational activities at the primary, lower secondary, and secondary levels are supervised by the Ministry of National Education. The Ministry supervises all institutions through central national policy. In terms of the way they are funded, there are two types of schools in Turkey-public and private-and both are supervised by the Ministry. Both types of schools have to comply with governmental policy and provide education based on a central curriculum designed by 
the Board of Education, a branch of the Ministry of National Education. From 2004 onwards, a new curriculum was implemented for primary and secondary schools in Turkey. The idea behind the current curriculum is to make it learner-centered and constructivist. The basic objectives of the curriculum in Turkey are to arrange the units thematically, to develop core competencies across the curriculum, to implement a student-centered constructivist model, to incorporate information communications technologies into instruction, to monitor student progress through formative assessment, to move away from the traditional assessment of recall, to introduce authentic assessment, and to enhance citizenship education (Board of Education, 2005).

Private schools can be established as mainstream schools as well as minority schools if they possess minority status. Unless they have separate law-abided schools concerning the minority status, all schools admit all students regardless of minority status. Law No. 5580 in Turkey defines and organizes the activities of private education institutions including those established specifically for minorities (Ministry of National Education, 2007). The law states that the minorities that are permitted by law to establish schools are the Greeks, Armenians, and Jews, meaning that the Syriacs are not allowed by law to establish private schools for their community.

In Turkey, the idea that the education system needs to be organized around multicultural and inclusive principles has been adopted by educators, scholars (e.g., Sakız, 2016; Sakız et al., 2015), and policymakers (e.g., Aktekin, 2017). The recent migration wave following the internal conflict in Syria as well as discussions concerning the flexibility of the educational system has required that the system possesses multicultural sensitivity towards the needs of students from diverse backgrounds. According to Sakız et al. (2015), the new educational ideology in Turkey, which focuses on multiculturalism and its principles such as inclusion, pluralism, and equity, is providing impetus and new opportunities to both policymakers and practitioners to establish an inclusive education system. This ideology has been adopted by policy as well; for example, in 2004 and 2008, the Regulation for Inclusive Education Practices (No. 2004/7) and the Regulation for Educational Practices through Inclusive Education (No. 2008/60) were published, respectively (Ministry of National Education, 2004, 2008). Also, the migration wave to Turkey has led policymakers (e.g., Aktekin, 2017) to consider strategies of meeting the needs of migrant students. However, in Turkey, inclusion policy has only been associated with specific groups, such as students with disabilities (Ministry of National Education, 2004, 2008) and Syrian migrants (Aktekin, 2017), without any focus on students from ethnic minorities.

Despite increased awareness among scholars and policymakers, enhancing the inclusiveness of the system to provide effective education for students with disabilities and migrants, including those from minority groups, is yet far from being adopted in Turkey. Moreover, apart from Law No. 5580, which concerns the establishment of private schools of Greek, Armenian, and Jewish minorities, the general policy does not refer to students from minority groups and the strategies to include them within the curriculum. Therefore, a multicultural perspective needs to be established within the Turkish education system and therefore major attempts are needed to include members of minority groups through school curricula. The recent efforts to design inclusive policy are observable. Nevertheless, students from minority groups may lack a sense of belonging to the school community and find it difficult to reach their potential.

In Turkey, studies on diversity and inclusion in education are mostly descriptive (e.g., Batu, 2010), focusing mostly on disability (e.g., Rakap \& Kaczmarek, 2010) and recently migration (e.g., Baban, Ilcan, \& Rygiel, 2017). However, no study focuses on minority groups and their experiences in schools. Although Syriacs have lived in the region for hundreds of years, little attention has been paid to their educational inclusion within the system. The current study focuses on members of this minority group and investigates their educational experiences from a multicultural perspective.

\section{Methods}

This study aims to investigate the educational experiences of Syriac individuals regarding inclusion within Turkish schools. To achieve this aim, a qualitative case study methodology was utilized. Using a qualitative methodology enables participants to express their experiences, thoughts, and feelings in depth, freely and the way they prefer, unlike many other methods that do not allow such freedom. This method is particularly useful with disadvantaged groups, including those with different ethnic and religious backgrounds because it hears the voice of vulnerable participants who are rarely listened to and allows them to explain their experiences (Liamputtong, 2007). Individuals from minority groups are often invisible in society and it is not easy for them to find opportunities to express their experiences.

The ethical aspect constitutes a significant side in inclusion research. To ensure maximum ethical conduct during the research, participants were provided with information about the aims, content, and procedures of the research to allow them to make a voluntary decision to join the research. Also, all participants were guaranteed that all personal information would be kept confidential; all names would be anonymized and nothing that could reveal their identities would be shared. Indeed, no names were shared in this study.

\subsection{Participants and Data Collection}

To investigate the experiences of Syriac individuals concerning their inclusion within Turkish schools, we conducted interviews with members of the Syriac community. 46 students (mean age $=15.4 ; 25$ males and 21 fe- 
males) attending pre-secondary $(n=18)$ and secondary ( $n=28$ ) level schools in Mardin district, Southeast Anatolia, and their 43 parents (mean age $=46.2$; 27 mothers and 16 fathers) were interviewed. It is not easy to find participants from vulnerable groups and ensure their voluntary participation in research. Therefore, two strategies were used to recruit participants. First, a convenient sampling method was used to get in touch with whoever was acquainted with the researchers and available at the time of the research. Living in the same city with the participants was an advantage; therefore 24 parents and their 26 children were directly contacted. Second, a snowball sampling method was used to reach potential participants. This method was useful in reaching 19 parents and their 20 children whom researchers would probably not be able to reach by any other means. There was no bias in selecting participants. Whoever was available was contacted regardless of what they thought about the research topic, aims, and questions.

To collect data, an interview schedule including 32 questions was prepared (see Supplementary File). In constructing the interview questions, the Index for Inclusion by Booth and Ainscow (2002) as well as the conceptual and empirical scholarship proposed by Sakız et al. (2015), Sakız and Woods (2015), Sakız (2016), Dyson et al. (2002), and Salend (2011) guided the process. Interviews are a useful method to collect participants' experiences and opinions in a detailed and rich manner. The interview schedule included 'yes-no questions' such as 'Do you think the staff at school hold the necessary expertise in their subject areas?' or 'Are you made to feel welcome at school?'. Also, the questions were the same for both parents and children. However, the semi-structured nature of the schedule allowed researchers to add 'why and how questions' such as 'Can you elaborate on this issue please?' or 'How satisfied are you with the policy and regulations?' to focus more on a particular issue and make changes based on the role of participants, whether they were children or parents. The questions were presented to parents so they could provide their opinions regarding their children's education while students were encouraged to speculate on their own experiences. However, some parents reflected on their own educational experiences too. On average, the interviews lasted 45 minutes with children and 52 minutes with parents. Throughout the interviews, an audio recorder was used for 76 interviews while 13 participants consented only for taking notes. All interviews were conducted in Mardin, a city with around 2,000-3,000 Syriac people. Out of 89 interviews, 71 were held at participants' flats and 18 at the workplaces of parents. As all participants and researchers could speak Turkish, all interviews were carried out in Turkish.

\subsection{Data Analysis}

To analyze the data collected via interviews, the researchers used a constant comparison method (Glaser
\& Strauss, 1967) involving a process of three cycles. The NVivo 10 software facilitated the organization of the data and its thematization. This process involved a hybrid approach, which incorporated a data-driven inductive approach (Boyatzis, 1998) and the deductive a priori template of codes approach (Crabtree \& Miller, 1999). This approach helped complement the research questions by allowing the process of deductive thematic analysis to include the tenets of inclusive education while allowing themes to emerge directly from the data using inductive coding. After careful reading of data, transcripts were selectively coded concerning the research question and the prevalence of each pattern. Transcriptions were conducted by the researchers. The next phase of the analysis included coding of the text to make meaning out of the data. Later, the initial codes were organized together to find any theoretical relationships between them. In addition to the initial inductive phases, a deductive approach was used at the final phase to reorganize the codes and categories influenced by the theoretical and methodological framework of the study. For the interview dataset, researchers sought participants' descriptions about their experiences and views of inclusion within the school system, leading to three over-arching themes associated with the culture, practice, and policy of the school system, and 13 sub-themes constituting the structure of the main themes (Figure 1).

\section{Findings}

This study mainly draws from the interviews conducted with Syriac students and their parents concerning students' inclusion within Turkish schools. The themes and sub-themes that were created from the analysis process are presented in the following sections.

\subsection{School Cultures}

On the majority of occasions, inadequate attention is given to the power of school cultures to support or undermine developments in teaching and learning. Yet, they are at the center of learning and development in a school. Besides, the development of common inclusive beliefs, values, and practices may lead to developments in other dimensions. In the interviews conducted with students and parents, elements of school culture were analyzed in terms of inclusion. Five sub-themes were identified out of the analysis.

\subsubsection{Syriac Community Inclusion within the School System}

One of the basic premises of inclusive education is to set collaboration between the school and the community. Therefore, inclusive school culture is characterized by the cooperation of all stakeholders within the entire educational process, especially in decision-making. In this study, participants' views referred to the way schools 


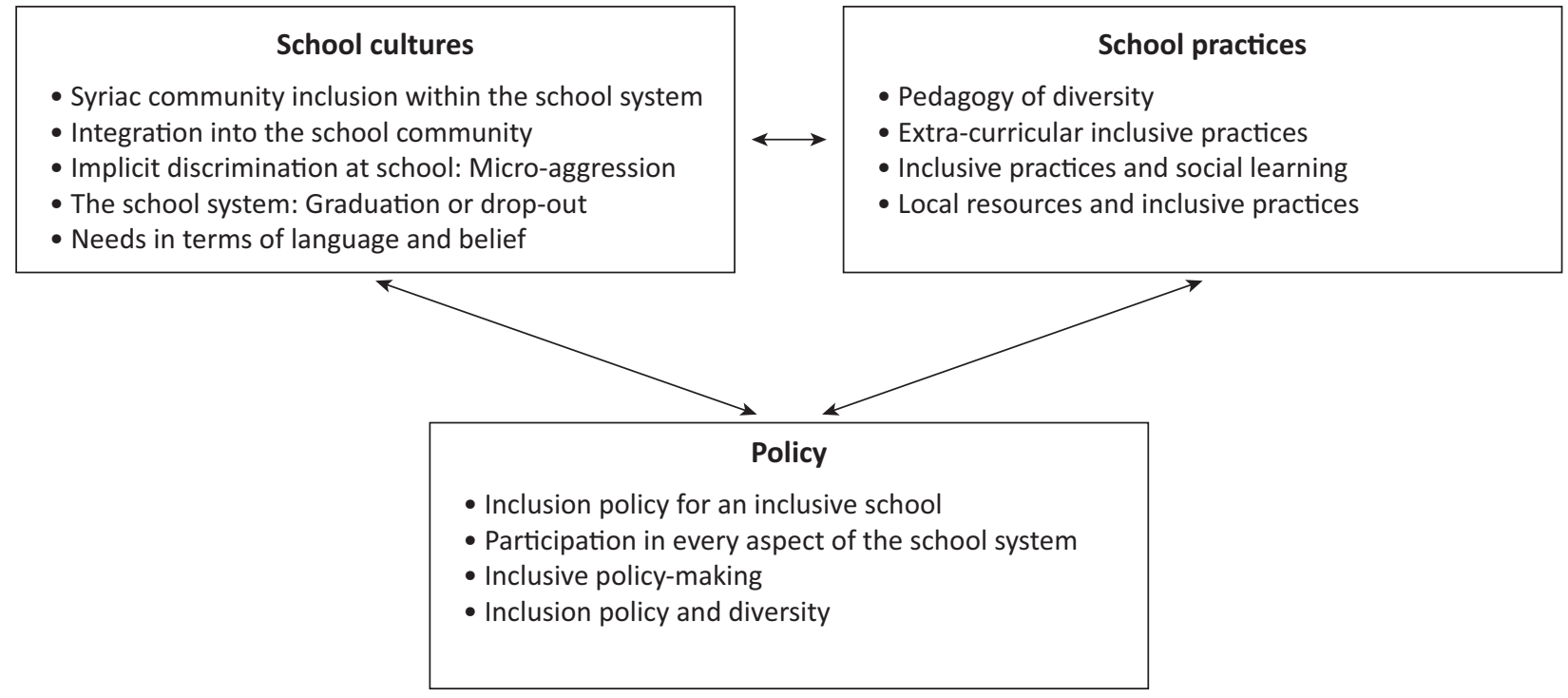

Figure 1. Map illustrating themes and sub-themes created out of the analysis of interview data.

attempted to include the Syriac community, specifically children and their families, within the school system. The majority of the parents stated that they did not feel like part of the school community $(n=34)$, that they believed being different in ethnicity and belief contributed to the detachment between the school and their community $(n=33)$, and that there was not an emphasis on family-school involvement $(n=27)$. However, some parents $(n=24)$ reported that they were available to assist with the concerns raised by schools regarding the education of their children. A parent illustrated this case by saying: "I never felt that my children and I are part of the school community. The boundaries are mostly invisible; however, I feel that there are barriers to our integration. Sometimes we may have to conceal that we are Syriac."

The inclusion of the local communities within the school in ways that partnerships are constructed to support education in the school is a requirement for the construction of inclusive school cultures.

\subsubsection{Integration into the School Community}

Despite the long-lasting history of living amongst a majority that is different culturally and ethnically, members of the Syriac community have succeeded to maintain their cultural inheritance throughout the centuries. This has been possible by preserving the main characteristics of their culture. Not surprisingly, this might have caused caution to the attempts by the majority to include them because, at the first instance, it may not be obvious whether the aim is to integrate or assimilate. As a result, some members of the Syriac community remained reserved and resistant to approach the mainstream community, often to preserve their identity and culture against perceived subordinating attempts. There were parents $(n=13)$ and students $(n=11)$ who reactively maintained the caution and preferred to stay outside the school community. For example, a parent said:
"I know we cannot benefit from the school too much. It is enough if our children receive a diploma because they [schools] are not in line with our culture."

Based on the aforementioned remarks, parents and students stated that there was a need for mutual collaboration and scaffolding to motivate both the majority and minority to achieve this. However, it is not easy to realize full collaboration to achieve inclusion in schools. Some hidden elements embedded within the school cultures, such as micro-aggressive behavior, can make inclusion difficult to achieve.

\subsubsection{Implicit Discrimination at School: Micro-Aggression}

Some verbal, written, or performative behaviors, which may seem positive at first glance, convey subtle messages that involve racial, ethnic, gender, and other stereotypes that can play out painfully in an increasingly diverse culture. These subtle messages are called 'microaggression' (Sue et al., 2007). The majority of the parents $(n=33)$ and children $(n=25)$ stated that they had positive verbal communication with school staff, other students, and their parents. During the face to face communication, at first sight, they were mostly exposed to positive remarks. However, the hidden messages embedded in communication involved elements that conveyed negative and discriminatory meanings. One student illustrated this case by saying: "My teacher always advises my friends to treat me well even when I am present at that moment."

Such hidden messages given to Syriac individuals existed within the data and were selected to represent micro-aggressive behavior. Some of these behaviors included statements such as "How can you speak Turkish quite well?," "Do you have any plans to leave here and start living with your relatives live in Europe?," "Don't worry! The race is not important, we all come from one 
God!", and "I have many Syriac friends and I get on well with all of them." Such brief and commonplace daily verbal expressions, whether intentional or unintentional, may communicate negative prejudicial slights toward any group, particularly culturally marginalized people.

\subsubsection{The School System: Graduation or Drop-Out}

A critical decision in the lives of many individuals from minority groups is to study in the schools of the majority or leave the system either to follow a vocational career or migrate to another country for alternative educational opportunities. Similarly, some participants in this study stated that they were indecisive about whether they should continue education because the schools lacked the quality to include them in ways that equip them with skills and knowledge necessary for after school life. Remarks of students $(n=23)$ and parents $(n=27)$ pointed to the shortcomings of schools to include Syriac individuals and, therefore, the need for schools to work harder to keep students within the education system. For those dropping out of school, alternative pathways were to join the workforce involving vocations such as jewelry or trade, which are characterized by the Syriac community or to leave the city and, most often, the country. A parent illustrated how the school could not offer an embracing environment whereby students could progress throughout levels by saying:

The school did not promise me enough to stay in the system. Thus I maintained my family job. Otherwise, I could not achieve what I wanted through schools. Furthermore, I could not gain the vocational skills needed to do the job I wanted.

Overall, participants in the study implied that school cultures need to contain an embracing environment whereby Syriac individuals feel a sense of belonging and foresee a fruitful future. Undeniably, the quality of education in a school concerns everyone. However, students from minority groups are more likely to feel the impact of low-quality education due to various disadvantages created by minority status. Achieving this aim requires improvement in the inclusiveness of school cultures to make schools appropriate places for all.

\subsubsection{Needs in Terms of Language and Belief}

Culture, religion, and language are often linked to each other. Inclusive education proposes that the variety of languages spoken and beliefs held by students should be an integral part of the curriculum and used as a resource for teaching and learning. This proposal is valid for the Syriac culture in Turkey, where some traditions and customs are directly related to Christianity. However, findings in this study showed that it is not sufficient to discuss the Syriacs solely in terms of religion: Language is equally important for them. However, parents and students re- sented that their needs in terms of their language and beliefs still needed to be met. One parent said: "We are citizens and we pay tax as other citizens do but they can receive education on their languages and religions whereas we cannot. Our children do not attend classes of other religions and stay outside the classroom." Participants often stated that there was a need to include objectives in the curriculum regarding the needs of individuals of the Syriac community. When students do not feel included within the curricular content, problems in socialization among students are likely to emerge.

\section{Policy}

Building an inclusive school culture is associated with the need that inclusion permeates all school plans. It is thanks to inclusive policies that students and staff get motivated to participate in the school, all local students are reached out, and exclusionary pressures are minimized. The interviews in this study yielded four subthemes related to policy.

\subsection{Inclusion Policy to Build a School for Everyone}

An inclusive school involves mechanisms that benefit all students in terms of learning and development. Developing the school for all, therefore, requires that policy targets development of all school staff to meet the diverse needs of students, the school seeks to overcome barriers to participation for the variety of ethnic groups in the locality, and therefore, achieves an increase in the diversity of students from the locality included in the school. In this study, parents $(n=19)$ and children $(n=20)$ reported that they were not satisfied with the school policy to offer students effective education, to carry out adequate staff development activities, to help all new staff and students to settle into the school, and to arrange teaching groups so that all students are valued. Due to the lack of inclusive policy to achieve these aims, according to most parents $(n=35)$, the number of Syriac students in schools has gradually decreased. To illustrate, one parent said: "The school does not have satisfactory rules to produce good outcomes for our children." Similarly, a student said: "Teachers mostly take care of the highest achieving students because the rule is not to teach everyone equally." All in all, participants stated that necessary political and legislative actions had to be taken to provide quality education to all students including those from the Syriac minority.

\subsection{Participation in Every Aspect of the School System}

Inclusion policy in education facilitates that all children, regardless of their background, are admitted and participate in every aspect of the school system without any barriers. The multicultural nature of the city of Mardin has created awareness among educational stakeholders to welcome students from different backgrounds. 
Relatedly, the majority of the parents $(n=26)$ stated that they did not have observable obstacles during the first admission to schools. However, participants stated that although the initial registration phase did not involve observable barriers, children hardly received adequate support to get admitted to and participate in other aspects of the school system such as classrooms, playgrounds, and curricula. To illustrate, a student reported: "I often feel that our culture is not integrated into the classes. For example, our habits, our traditions...they are not in books." Similarly, a parent reflected on the importance of active engagement with learning and having a say in how education is experienced, saying: "I think teachers should do more to provide our children more opportunities to learn alongside others and collaborate with them in shared activities and experiences." Overall, participants often stated that admission is not only about registration; it also means active participation in every aspect of the school. This requires an inclusive way of policy-making.

\subsection{Inclusive Policy-Making}

An inclusive way of policy-making requires that whoever has a say in the education system is heard and included within the planning and implementation of the policy. Therefore, policy-making should not be a onesided activity. In this study, a few parents $(n=3)$ and students $(n=6)$ stated that they were individually consulted while giving decisions about them. For example, they were asked about what could be done for their children to learn better. However, the majority of the parents $(n=24)$ stated that there was hesitation among school managers to approach them, especially because their needs, which involved learning their native culture, language, and belief, were difficult to meet within a central curriculum which focuses predominantly on Turkish culture and the religion of Islam. One parent illustrated this case by saying: "Our needs include courses for our culture, spiritual counseling, and more opportunities. Noone aims to meet them." Similarly, students felt that they were not approached adequately by teachers for their educational needs. One student said: "Not all diverse student needs are taken into account. I feel the school is made for whoever is the majority." Overall, participants stated that the extent to which the school attempted to meet the needs of Syriac students was questionable.

\subsection{Inclusion Policy to Support Diversity}

An important premise of inclusive education is that diversity is seen as an opportunity to enhance the variety of teaching and learning opportunities. Therefore, creating a school that provides learning and development opportunities for children of minority groups requires that support be organized for diversity and that all support policies be coordinated in a strategy for increasing the capacity of the school to respond to diversity. In this study, the students and parents held mixed opinions as to whether support is coordinated well in their schools. For example, a student said: "We are like others because we speak Turkish and we are the same. They [staff] are lucky otherwise they would not do anything to help us in education." Generally, participants stated that schools needed better regulations to counter anti-social behavior, to change beliefs favoring bullying and racism, and to address feelings of devaluation when they arise among Syriac students.

\section{School Practices}

Schools that are inclusive of students with different ethnic and religious minorities orchestrate learning and mobilize resources in ways that students' individual and educational needs are met, that they achieve their learning potential and that they do not feel discriminated against in comparison to citizens who belong to the official identity. In this study, Syriac parents and students were interviewed about whether the school practices helped to achieve their inclusion. The findings are presented below.

\subsection{Pedagogy of Diversity}

Inclusive schools are characterized by the pedagogy of diversity where students from different ethnic backgrounds feel belonging to the class, access the curriculum, and improve their knowledge and skills. The issue stated by parents $(n=19)$ was the lack of support given to teaching staff to improve teaching and learning and raise the feelings of self-worth among children of the minority. For example, a student stated that: "In primary school, paired and group activities in class always included the same people and I was not very popular to include." Both student and parent comments implied that support was needed in classes that address barriers to learning in all aspects of teaching, curricula, and school organization.

\subsection{Extra-Curricular Inclusive Practices}

In addition to the inclusiveness of classes, participants were asked about whether everyone with different ethnic backgrounds took part in activities outside the classroom. Mostly, parents $(n=18)$ felt that they volunteered to be part of the school community for their children's benefits. However, a considerable number of parents ( $n=24$ ) felt that the opportunities to take part in activities outside the classroom did not address their children adequately, and therefore, children could not socialize with each other sufficiently. Participants mentioned a lack of practices such as culture clubs, sports, community services, arts, and skill-based games that would support the development of students. A parent said that "Our school system is mostly based on teaching and rote learning in the classroom. When there are activities, these do not support or benefit local communities," while a stu- 
dent said that "In primary school, teachers used to convince others to do activities with me outside the classroom because they were not eager." Participants stated that schools needed to facilitate collaboration and inclusion within heterogeneous groups among students outside the classroom.

\subsection{Inclusive Practices for Social Learning}

The idea of inclusion is closely associated with the principles of social learning such as peer relations, modeling, and cooperation. However, participants in this study stated that implicit and explicit ways of categorizing students based on ethnicity and religion prevented opportunities for cooperation, collaboration, and social support. There were, of course, cases where students made good friendships and socialized together. However, the majority of parents $(n=33)$ and students $(n=27)$ reported that the social relations among students of different cultures were not satisfactory. For example, a parent said: "People do not teach their children how to live together. Religion is very important to them. Because of that, children separate in schools instead of learning from each other." Also, a student reported that: "We are mostly alone during classes." A lack of constructive human relations among parents was also reported. For example, a parent said: "There are competition and separation between families, rather than socialization and cooperation." Overall, participants indicated that more cooperation, collaboration, and socialization were required in classes to achieve a positive classroom atmosphere respecting diversity.

\subsection{Local Resources to Develop Inclusive Practices}

In inclusive schools, community resources are known, drawn upon, and used to support teaching and learning. Where there are minority groups, schools are expected to communicate with local stakeholders that represent these groups and consider their ideas and needs. In Mardin, the most important stakeholders when it comes to the education of Syriac students are the families, the church, and cultural NGOs, who can provide awareness and religious and linguistic education for Syriac people. Indeed, given the recent popularity of the city of Mardin in terms of its cosmopolitan structure, there is a tendency to investigate the different cultures within the city. However, participants of this study reported that although stakeholders representing the Syriac community were eager to collaborate with the school and contribute to the curriculum, there was still a one-way flow of interest, information, and contribution. Schools rarely attempted to benefit from the experiences of the local Syriac community to improve education in ways that Syriac children receive good quality education. For example, a parent said: "Books are full of elements of major cultures, religions, and languages. The Syriac culture is absent from the entire curriculum and coursebooks."
Overall, participants pointed to the need for stronger bonds between schools and the local community.

\section{Discussion}

This study aimed to investigate the experiences of Syriac students and their parents regarding their inclusion within Turkish schools. Scholarship in the related literature such as the Index for Inclusion (Booth \& Ainscow, 2002) as well as other sources (e.g., Dyson et al., 2002; Salend, 2011) provided the conceptual and methodological framework and helped to thematize the findings under three overarching themes: school culture, policy, and school practices.

The main aim of inclusive education is to offer equitable education of good quality to all learners (UNESCO, 2015). Achieving this aim entails that school practices ensure physical and social participation, facilitate learning, and equip students with skills for transition to adult life (Scruggs, Mastropieri, \& McDuffie, 2007). However, the findings of this research showed that students and parents were not satisfied with the attempts of schools to provide quality education to Syriac students. Learning and development in several areas (e.g., academic, psychosocial) were usually perceived by students and parents as insufficient.

Inclusive education is seen as a collective effort to grant the right to belong to the school community (Falvey \& Givner, 2005) following the approach of 'education for all.' The current study focused on the relationships between inclusive education and psychological, social, and educational development. Problems or deficiencies in psychosocial processes lead to problems in educational development because psychosocial development affects the extent to which students are supported in classrooms (Knefelkamp, Widick, \& Parker, 1978). At this point, the school culture has a crucial place in the education system because the way people grow and develop throughout their lifespan affects their psychosocial development during school life.

Some participants believed that being in the same school was positive in terms of developing a culture of living together. However, reports of the majority of students and parents showed that one should not accept that academic and social-emotional skills develop automatically when students are brought together physically. Furthermore, enhancement of social-emotional skills may not necessarily indicate inclusion within all aspects of the school and community. Syriac students reported that they often lacked the feeling of being included within the school atmosphere, classes, and activities outside the classroom. However, when implemented properly, inclusive education improves socialemotional well-being among students (Black-Hawkins, Florian, \& Rouse, 2007) because inclusive education can be founded on the principles and arguments of social learning and developmental theories. These arguments support that peers can learn and develop socially and 
cognitively through observation, modeling, and scaffolding (Vygotsky, 1978).

Exclusionary practices that hinder the development of inclusive values in a school culture may be both explicit and implicit. In this study, students and parents reported implicit micro-aggressions, which are brief and commonplace daily verbal, behavioral, and environmental indignities, whether intentional or unintentional, that convey negative and hostile racial messages to the target person or group (Sue et al., 2007). Micro-aggressive behaviors as reported by the participants were not limited to human encounters alone but were also environmental, as when Syriac students were exposed to a school or classroom environment that unintentionally assailed their identity. For example, one's cultural identity can be minimized or made insignificant through the sheer exclusion of elements or literature that represents various cultural groups.

Human development contains interacting factors such as a sense of self (religious, ethnic, cultural identity, etc.), emotions, competency, and integrity. Therefore, if the school curriculum is not inclusive, student development could face barriers, leading to a decrease in achievement. One of the basic principles of inclusive education is the attempt to make the curriculum accessible to all students and empower students to maximize their learning within the curriculum content (Williams \& Reisberg, 2003). In this study, reports showed that some Syriac individuals either leave the education system for another region/country or drop out completely to join the workforce, often due to an unpredictable future after graduation. The failure of schools to promise a good future is a problem for everyone. However, students of minority groups may be less optimistic about their future due to minority status. This requires schools to consider the characteristics and needs of minority students while planning education and instruction. Also, participants reported that the central curriculum did not possess cultural flexibility to enable Syriac students to participate in classroom activities which required input from students' cultures. Participants suggested that the general curricula needed to get designed flexibly to reflect cultural elements such as language, customs, and religion and, therefore, allow all students to participate within the curriculum content. The fact that some Syriac children are not able to receive education in line with their culture may have a direct consequence on the almost extinct Syriac culture. In such a scenario, the failures of minority group members in the schooling process may not be the failure of the students themselves (Maekawa, McEwen, Liang, \& Lee, 2002) but rather the inadequacy of the school curriculum which is affecting their social and emotional adaptations, school achievement, integrity, and competency.

Opinions of the families about the education of their children are important to the extent they participate in this process. In this study, a considerable number of Syriac parents reported that their children wanted to be valued and respected in the school as main members of the school community. They usually thought that their students were tolerated in the school, and this created the feeling of exclusion from the school community because of the difference between their children. However, the quality of communication and collaboration between schools and families matters and is expected to create positive results in terms of learning. It was revealed in this study that there was communication between parents and the school. However, this was far from producing effective outcomes. Most parents stated that they were interested in their children's education; however, only a small percentage of them thought that the school took their concerns seriously.

The case illustrated in the findings of this study points to the significance and need to employ effective approaches to design and implement inclusive practices to ensure that students from different ethnic backgrounds learn and participate in classrooms. Participants reported that one reason for the limited success in terms of the effectiveness of the school practices in terms of Syriac students was the inadequacy to locate and remove barriers to learning by providing support and designing structures to ensure participation and progress. For example, these practices could involve effective teaching, pastoral care, counseling, and extracurricular activities. However, this needs to be done in a school culture where students are not separated by educators as mainstream students and others (Slee, 2006). Achieving this requires competent and knowledgeable educators.

The inclusion of students with different backgrounds within the education system is not a matter only for families and schools (Beveridge, 2005). This study has shown that inclusion is associated with local and national policies. The limited success located at the policy level was related to the lack of inclusion policy that requires everybody, regardless of background and status, to be treated as main members of society, and any individual needs to be met within the framework of the social, educational, health, and other services available to all members of society. Another reason was that actors from various layers of society were not interconnected to contribute to the process of establishing inclusive policies (Wendt, 1999). However, these actors may contribute to the creation and application of flexible education systems that match the increasingly diverse characteristics of individuals and communities.

\section{Limitations, Recommendations, and Conclusion}

Despite the many strengths of the current study, there were some limitations. First, the findings of this study are limited to the views and experiences of parents and students, making it difficult to draw general conclusions about the school system. Therefore, data from other sources could reveal different aspects of the system in Turkish schools. Second, the sample was located in a single city where there are around 2,000-3,000 Syriac in- 
dividuals. However, in future studies, participants from other cities where the Syriac community predominantly lives (e.g., Istanbul) can also be employed and represent the dynamics of schools in other regions.

In conclusion, it can be argued that the inclusion of students with different backgrounds entails that the members of such a group shall not be denied the right to enjoy and practice their own culture, while their needs are met within the education system. Therefore, these individuals who hold different needs and characteristics are given extra support in addition to individual rights. From a pluralist point of view, it is believed that genuine inclusion and equality can be accomplished by recognizing the different needs of different people and meeting these needs in particular ways that address their background. The recognition of the needs and characteristics of Syriacs is thus a requirement to treat them equally and make them the main members of the school system. Recently, Turkey has made serious advancements to make the system inclusive to students with different needs and backgrounds. Although these advancements are promising, there is still a long way to go. Despite advancements, the Syriacs of Turkey need to be remembered and considered more within the education system. The recent steps taken at the political, conceptual, and practical levels should be maintained to open paths to the establishment of truly inclusive schools that achieve the task of maximizing the learning and development of everyone.

\section{Acknowledgments}

The authors thank the students and parents who joined the study and provided their valuable opinions.

\section{Conflict of Interests}

The authors declare no conflict of interests.

\section{Supplementary Material}

Supplementary material for this article is available online in the format provided by the author (unedited).

\section{References}

Aktekin, S. (Ed.). (2017). Sınıfında yabancı uyruklu öğrenci bulunan öğretmenler için el kitabı [A manual for teachers whose classes include international students]. Ankara: Ministry of National Education.

Baban, F., Ilcan, S., \& K. Rygiel. (2017). Syrian refugees in Turkey: Pathways to precarity, differential inclusion, and negotiated citizenship rights. Journal of Ethnic and Migration Studies, 43(1), 41-57.

Bardakci, M., Freyberg-Inan, A., Giesel, C., \& Leisse, O. (2017). Religious minorities in Turkey: Alevi, Armenians and Syriacs and the struggle to desecuritize religious freedom. London: Palgrave Macmillan.

Batu, E. S. (2010). Factors for the success of early child- hood inclusion \& related studies in Turkey. International Journal of Early Childhood Special Education, 2(1), 57-71.

Beveridge, S. (2005). Children, families and schools: Developing partnerships for inclusive education. London and New York, NY: Psychology Press.

Black-Hawkins, K., Florian, L., \& Rouse, M. (2007). Achievement and inclusion in schools. Oxon: Routledge.

Board of Education. (2005). Talim ve Terbiye Kurumu Başkanlığı ilkögretim 1-5. Sınıf programları tanıtım el kitabı [Board of Education, handbook of elementary school mathematics curriculum (1-5th grades)]. Ankara: Milli Eğitim Bakanlığı.

Booth, T., \& Ainscow, M. (2002). Index for inclusion: Developing learning and participation in schools. Bristol: Centre for Studies on Inclusive Education.

Boyatzis, R. (1998). Transforming qualitative information: Thematic analysis and code development. Thousand Oaks, CA: Sage.

Crabtree, B., \& Miller, W. (1999). A template approach to text analysis: Developing and using codebooks. In B. Crabtree \& W. Miller (Eds.), Doing qualitative research (pp. 163-177). Newbury Park, CA: Sage.

Dyson, A., Howes, A., \& Roberts, B. (2002). A systematic review of the effectiveness of school-level actions for promoting participation by all students (EPPI-Centre review, version 1.1): Research evidence in education library. London: EPPI-Centre.

Falvey, M. A., \& Givner, C. C. (2005). What is an inclusive school? In R. A. Villa \& J. S. Thousand (Eds.), Creating an inclusive school (2nd ed.) (pp. 1-12). Alexandria, VA: Association for Supervision and Curriculum Development.

Glaser, B. G., \& Strauss, A. L. (1967). The discovery of grounded theory: Strategies for qualitative research. New York, NY: Aldine de Gruyter.

Içduygu, A., Toktas, Ş., \& Soner, B. A. (2008). The politics of population in a nation-building process: Emigration of non-Muslims from Turkey. Ethnic and Racial Studies, 31(2), 358-389.

Knefelkamp, L., Widick, C., \& Parker, C. A. (1978). Editors' notes: Why bother with theory? New Directions for Student Services, 1978(4), vii-xvi.

Liamputtong, P. (2007). Researching the vulnerable: $A$ guide to sensitive research methods. London: Sage.

Maekawa, K. C., McEwen, M. K., Liang, C. T., \& Lee, S. (2002). An Asian American perspective on psychosocial student development theory. New Directions for Student Services, 2002(97), 45-60.

Ministry of National Education. (2004). Kaynaştırma uygulamaları genelgesi [Inclusive practices regulation]. Ankara: Ministry of National Education.

Ministry of National Education. (2007). Özel öğretim kurumları kanunu [Law regulating private education institutions]. Ankara: Ministry of National Education. Retrieved from https://www.mevzuat.gov.tr/ MevzuatMetin/1.5.5580.pdf

Ministry of National Education. (2008). Kaynaştırma 
yoluyla eğitim uygulamaları genelgesi [Educational practices through inclusion]. Ankara: Ministry of National Education. Retrieved from https://orgm. meb.gov.tr/meb_iys_dosyalar/2015_10/08101631_ kaynatrmayoluylaeitimuygulamasgenelgesi.pdf

Rakap, S., \& Kaczmarek, L. (2010). Teachers' attitudes towards inclusion in Turkey. European Journal of Special Needs Education, 25(1), 59-75.

Sakız, H. (2016). Thinking change inclusively: Views of educational administrators on inclusive education as a reform initiative. Journal of Education and Training Studies, 4(5), 64-75.

Sakız, H., \& Woods, C. (2015). Achieving inclusion of students with disabilities in Turkey: Current challenges and future prospects. International Journal of Inclusive Education, 19(1), 21-35.

Sakız, H., Woods, C., Sart, H., Erşahin, Z., Aftab, R., Koç, N., \& Sarıçam, H. (2015). The route to 'inclusive counselling': Counsellors' perceptions of disability inclusion in Turkey. International Journal of Inclusive Education, 19(3), 250-269.

Salend, S. J. (2011). Creating inclusive classrooms: Effective and reflective practices (7th ed.). Boston, MA: Pearson.

Scruggs, T. E., Mastropieri, M. A., \& McDuffie, K. A. (2007). Co-teaching in inclusive classrooms: A metasynthesis of qualitative research. Exceptional Children, 73(4), 392-416.

Slee, R. (2006). Limits to and possibilities for educational reform. International Journal of Inclusive Education, 10(2-3), 109-119.

Sue, D. W., Capodilupo, C. M., Torino, G. C., Bucceri, J. M., Holder, A., Nadal, K. L., \& Esquilin, M. (2007). Racial microaggressions in everyday life: Implications for clinical practice. American Psychologist, 62(4), 271-284.

Thomsen, J. (2008). The Assyrians/Syriacs of Turkey: A forgotten people (Unpublished Master's thesis). Malmo University, Malmo, Sweden.

Turkish Statistical Institute. (2020). Address-based census results. Turkish Statistical Institute. Retrieved from http://www.turkstat.gov.tr/Start.do

UNESCO. (2009). Policy guidelines on inclusion in education. Paris: UNESCO.

UNESCO. (2015). EFA global monitoring report: Education for all 2000-2015 achievements and challenges. Paris: UNESCO.

United Nations General Assembly. (1949). Universal declaration of human rights (Vol. 3381). Washington, DC: United States Department of State.

Vygotsky, L. (1978). Interaction between learning and development. Readings on the Development of Children, 23(3), 34-41.

Wendt, A. (1999). Social theory of international politics. Cambridge: Cambridge University Press.

Williams, G. J., \& Reisberg, L. (2003). Successful inclusion: Teaching social skills through curriculum integration. Intervention in School and Clinic, 38(4), 205-210.

Yıldız, I. (2007). Minority rights in Turkey. Brigham Young University Law Review, 2007(3), 791-812.

Yıldız, I. (2009). Din Kültürü ve Ahlak Bilgisi dersi: Zorunlu mu kalmalı, yoksa seçmeli mi olmalı? [The religious culture and ethics course: Should it be optional or compulsory?]. Tübav Bilim Dergisi, 2(2), 243-256.

Yıldız, S. (2002). Türkiye'deki Alevilerin din eğitiminden beklentileri [Expectations of the Alevis in Turkey from religious education] (Unpublished Master's thesis). Sakarya University, Sakarya, Turkey.

\section{About the Authors}

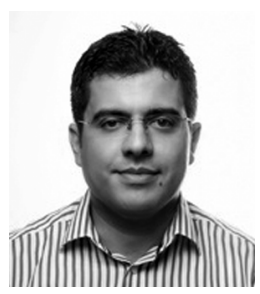

Halis Sakız is an Associate Professor of Educational Psychology in the Department of Educational Sciences, Mardin Artuklu University, Turkey. He has published in top-ranking journals and publishers on topics including inclusive education, school psychology, counseling psychology, psycho-educational assessment, and migration.

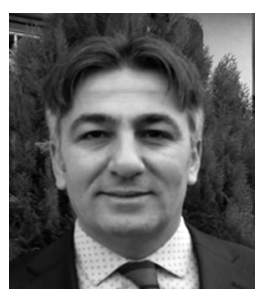

Abdurrahman Ekinci is a Professor of Educational Management and Leadership in the Department of Educational Sciences, Mardin Artuklu University. His research interests include educational management and leadership, specifically focusing on servant leadership. He has coordinated several EU projects and managed numerous theses to improve educational management and outcomes in local contexts.

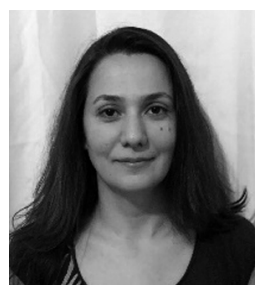

Güldest Baş is a Research Assistant in the Department of Psychology, Mardin Artuklu University. She obtained a master's degree in Applied Social Psychology at Royal Halloway University of London. She is a PhD Candidate in the Department of Social Psychology, Bursa Uludağ University, Turkey. She investigates how values and social beliefs of ethnic minorities-such as Kurds, Syriacs, and Arabs-affect their attitudes towards outgroup members. 